\title{
Coastal Dune Restoration in El Inglés Beach (Gran Canaria, Spain): a Trial Study
}

\section{Experiencia de Restauración de la Duna Costera de la Playa del Inglés (Gran Canaria, España)}

\author{
Abel Sanromualdo-Collado \\ abel.sanromualdo@ulpgc.es @ 0000-0001-5368-9604 \\ Antonio I. Hernández-Cordero \\ hernandez.cordero@ulpgc.es (1) 0000-0002-8373-9235 \\ Manolo Viera-Pérez \\ viera.manolo@gmail.com (1) 0000-0001-9547-2083
}

\begin{abstract}
Instituto de Oceanografía y Cambio Global, Universidad de Las Palmas de Gran Canaria. Parque Científico Tecnológico Marino de Taliarte, s/n. 35214 Telde, Las Palmas.

Juan B. Gallego-Fernández

jbgalfer@gmail.com (1) 0000-0002-4952-3449

Fundación Internacional para la Restauración de Ecosistemas.

C/ Princesa 3 dpdo, $7^{a}$ planta, apartamento 703. 28008 Madrid.

Luis Hernández-Calvento

luis.hernandez.calvento@ulpgc.es (1) 0000-0002-4948-7230

Instituto de Oceanografía y Cambio Global, Universidad de Las Palmas de Gran Canaria. Parque Científico Tecnológico Marino de Taliarte, s/n. 35214 Telde, Las Palmas.
\end{abstract}

INFO ARTÍCULO

Received: 01-12-2020

Revised: 22-01-2020

Accepted: 25-01-2021

\section{KEYWORDS}

Maspalomas

Sand collector

Arid beach-dune system

Nebkha

\section{PALABRAS CLAVE}

Maspalomas

Captador de arena

Sistema playa-duna árido

Nebkha

\section{ABSTRACT}

A trial study of foredune restoration on El Inglés beach (Gran Canaria, Spain) was carried out between July 2018 and December 2019 as part of the MASDUNAS program of the Gran Canaria Island Council. Among the objectives of that project was the sand relocation from the tip of La Bajeta to the El Inglés beach, the installation of sand collectors and the reintroduction of specimens of Traganum moquinii that act as generators of new mound dunes in the foredune. This study presents results, extracted from the scientific monitoring of the project, on the efficiency of the sand collectors and the evolution of the planted specimens of T. moquinii. The knowledge gained from this trial study is key to improve and adapt the coastal dune restoration procedure in arid systems.

\begin{abstract}
RESUMEN
La experiencia de restauración de la duna costera de la playa del Inglés (Gran Canaria, España) se realizó entre los meses de julio de 2018 y diciembre de 2019, dentro del programa MASDUNAS del Cabildo de Gran Canaria. Entre los objetivos de este proyecto se incluyeron la reposición de arena desde la punta de la Bajeta a la playa del Ingles, y la instalación de captadores de arena y reintroducción de ejemplares de Traganum moquinii que actúen como formadores de nuevas dunas monticuladas en la foredune. Este estudio presenta resultados, extraídos del seguimiento científico del proyecto, sobre la evolución de los captadores y de los ejemplares de T. moquinii plantados. El conocimiento extraído de esta experiencia es clave para mejorar y adaptar el procedimiento de restauración de dunas costeras en sistemas áridos.
\end{abstract}




\section{INTRODUCTION}

The restoration of degraded coastal dune systems has been carried out in many parts of the world, mostly in temperate areas such as Europe, the United States and South Africa (Lithgow et al., 2013). As a result, extensive knowledge has been gathered in these areas and different methodologies developed to restore this type of coastal dune characterized by the presentation of a continuous ridge morphology parallel to the coast and mainly vegetated by perennial herbaceous species (Ley et al., 2007; Nordstrom, 2008). However, considerably fewer studies have been carried out on arid dune systems (Burke et al., 2011; Lubke, 2013), and no specific methodology has been developed to date for the purposes of restoration. On arid coasts, the foredune is usually made up of mound dunes, commonly known as nebkhas, in which the vegetation tends to be shrub species. This is the case in the Canary Islands (Hernández-Cordero et al., 2019), northwest Africa (Hesp et al., 2021) and Chile (Castro Avaria, 1987; Castro, 1988), among other places.

The restorations carried out in different dune environments have been, in descending frequency, in stabilized dunes, semi-mobile dunes, mobile dunes and dune slacks (Lithgow et al., 2013). In mobile dunes, one of the landforms most degraded by human activities is the foredune.

Regardless of the dune region, two main types of coastal dune restoration techniques can be distinguished (Ley et al., 2007): engineering techniques and ecological techniques. While the former simply contemplate the use of machinery for the reconstruction of the dune topography, ecological techniques are based on the recovery of geomorphological and ecological processes that allow the dune formation, restoring the morphology and characteristic vegetation according to the area where the intervention takes place (Ley et al., 2007). For this, native dune-building species that accumulate sand while consolidating the dune that is being formed can be planted, or sand can first be accumulated with passive collectors with revegetation taking place later (Gómez-Pina et al., 2002; Ley et al., 2007; Nordstrom, 2008).

The objectives of foredune restoration include the supply of sediments to the corresponding beaches, the recovery of morpho-ecological states and sedimentary dynamics, the restoration of natural vegetation and endemic species, the creation of refuge habitats, the protection of human infrastructures, the creation of leisure areas and the recovery of landscape values (Martínez et al., 2013). The restoration of coastal dunes in arid regions has been based fundamentally on facilitating the colonization of key plant species for the formation of this landform, as is the case of Salsola nollothensis in Namibia (Burke et al., 2011).

A few dune restoration projects have been carried out in the Maspalomas dunefield, located in the south of the island of Gran Canaria (Canary Islands, Spain). Between 2005 and 2007, the "2006-2007 T. moquinii repopulation project" (original title in Spanish: Proyecto piloto de refuerzo de las poblaciones de balancones 2006-2007) was undertaken, promoted by the Gran Canaria Island Council, the governmental body in charge of managing the Dunas de Maspalomas Special Nature Reserve, and executed by the public company Gesplan. This project involved collecting Traganum moquinii (known locally as balancón) cuttings and seeds, transplantation and germination tests, the installation of fences, transportation and in situ planting and, finally, the monitoring of the evolution of plant growth (Gesplan, 2007). Unfortunately, most of these plants were planted too close to free dunes and were buried by them.

Another intervention was undertaken by the Gran Canaria Island Council in 2008 in the foredune area, consisting of the installation of sand collectors and the planting of associated $T$. moquinii specimens. At first, the type of collector used, a $2 \mathrm{~m}$ long double semicircular row of wicker rods to generate nebkhas, was effective and generated dunes. However, this action was ultimately unsuccessful as none of the plants survived (Fernández-Cabrera et al., 2011), most probably due to poor control by the administrative authorities of foredune use by public as well as a lack monitoring and maintenance of the actions that had been carried out.

The environmental changes that Maspalomas dunefield has experienced as a result of tourism development include: i) changes in geomorphological processes and types of landform due to modification of the aeolian sedimentary dynamics as the result of the construction of buildings and other infrastructure (Hernández-Calvento et al., 2014; Smith et al., 2017; García-Romero et al., 2019); ii) changes in vegetation, especially the decrease in the number of $T$. moquinii specimens, a plant species that generates the foredune 
and regulates the transport of sand into the system (Hernández-Cordero et al., 2017, 2018; García-Romero et al., 2021); and iii) alteration of the landscape as a consequence of massive and disorderly public use (Cabrera-Vega et al., 2013; García-Romero et al., 2016). To deal with this problem, a pilot study to relocate sand from the tip of La Bajeta to El Inglés beach (called in Spanish: Experiencia piloto de reposición de arena de la punta de La Bajeta a Playa del Inglés) was initiated in July 2018 as part of the MASDUNAS program run by the Gran Canaria Island Council, with a budget of 1,155,018.33€ and a duration of 18 months. The objectives of this project included, as well as the sand relocation, the installation of sand collectors and the reintroduction of $T$. moquinii specimens, which act as builders of new dunes in the foredune. To evaluate these objectives, the project included the development of a scientific monitoring program.

This study presents a first exploration of the results of the scientific monitoring that was carried out on the efficiency of the sand collectors and the evolution of the specimens of $T$. moquinii that were planted as part of the project. The objective was to evaluate the extent to which the sand collectors and $T$. moquinii specimens contributed to the formation of mound dunes and to expand knowledge of the geo-ecological processes of the foredune of El Inglés beach. The results of the scientific monitoring of this experimental study will help to improve and adapt methodologies for the ecological restoration of foredunes in arid dune systems.

\section{STUDY AREA}

The Maspalomas dunefield $\left(27^{\circ} 45^{\prime} 38^{\prime \prime} \mathrm{N}, 15^{\circ} 35^{\prime} 09^{\prime \prime} \mathrm{W}\right)$ is located in the southern vertex of the island of Gran Canaria on a deltaic platform at the mouth of the Maspalomas-Fataga ravine. At the south of the dunefield, the Maspalomas beach extends eastwards from the mouth of the Fataga ravine to the La Bajeta tip. The eastern boundary of the dunefield corresponds to El Inglés beach, aligned in a north-south direction, and is the main sediment supply to the dunefield. The beach stretches for 2,500 meters from the cliff of the El Inglés upper terrace (about $25 \mathrm{~m}$ above sea level), in the north, to La Bajeta tip, in the south. From the foreshore and up to $200 \mathrm{~m}$ into the dunefield there are specimens of the T. moquinii shrub. These plants, aligned from north to south, act as a dune-buider species and are responsible for the first natural retention of the sediments that advance inland. Their growth is stimulated by sand burial, which favors the formation of mound dunes (nebkhas). This first line of vegetated dunes forms the foredune of El Inglés beach. Its functions include the regulation of aeolian sedimentary transport into the dune system, the reduction of erosive processes and the promotion of the formation of barchan dunes and barchanoid ridges (Hernández-Cordero et al., 2012; Viera-Pérez, 2015). The height of the nebkhas that form the foredune of El Inglés beach ranges from 1 to 5 meters, associated to T. moquinii individuals that may reach $5 \mathrm{~m}$ in some cases (Hernández-Cordero et al., 2012; García-Romero et al., 2021) (Fig. 3C).

The climatic characteristics of this environment are arid: the average temperature of $21^{\circ} \mathrm{C}$ varies only slightly over the year, and mean annual precipitation is around $81 \mathrm{~mm}$. The winds have two main directions: those from the W, which represent $19 \%$ of the annual frequency, and those from the E-ENE, which account for $15 \%$ (Hernández-Cordero et al., 2019). However, as the latter are the most intense (effective winds), the wind and marine sedimentary dynamics occur in the NE-SW direction (Máyer Suárez et al., 2012). The winds from the $\mathrm{W}$, normally caused by the drift of the trade winds to the northern component and conditioned by the orography of the island, are usually mild (Viera-Pérez, 2015; Smith et al., 2021).

Several studies have confirmed a relative stability of El Inglés beach at different time scales (Alonso et al., 2001; Fontán-Bouzas et al., 2019; Di Paola et al., 2020). However, seasonally strong winds and energetic waves from the WSW-SW, associated with autumn-winter Atlantic storms, reverse the marine dynamics, and erode the Maspalomas beach. These storms are responsible for a significant sediment loss in the system (Fontán-Bouzas et al., 2019; Di Paola et al., 2020). In this context, sediments are transported eastwards to the the tip of La Bajeta, which grows until reaching a maximum limit marked by a drop-off. Consequently, part of the sand falls to deeper areas (below $20 \mathrm{~m}$ ) where the waves are unable to recover the sediment and transport it back to the beach. In recent decades, the system has lost an average of $45,000 \mathrm{~m}^{3}$ of sediment per 
year (Ministerio de Medio Ambiente, 2007), resulting in the identification of a sedimentary deficit (Hernández-Calvento, 2006). The consequences have been smaller dunes and a decrease in the area occupied by mobile dunes (Hernández-Calvento, 2006; Hernández-Cordero et al., 2017, 2018).

El Inglés beach is an area of considerable recreational activity, as it is one of the main areas of tourist development on Gran Canaria island. This intensive human activity has consequently had certain impacts on the foredune (Hernández-Cordero et al., 2017; Peña-Alonso et al., 2018; Viera-Pérez et al., 2019) that have led to its deterioration and fragmentation (Sanromualdo-Collado et al., 2021). The presence of discontinuities in the foredune of El Inglés beach due to the decrease in the number of $T$. moquinii specimens and the disappearance of the associated dunes has resulted, in turn, in an acceleration of the aeolian sedimentary transport and the formation of deflation surfaces (Pérez-Chacón et al., 2007; Hernández-Cordero et al., 2012).

For this work, the study area extends longitudinally from north to south from El Inglés beach to the tip of La Bajeta, forming a polygon of about 1,200 $\times 400 \mathrm{~m}$ which includes the sand extraction area, the storage area, the sand collector zones and the sand relocation areas specified in the aforementioned Experiencia piloto de reposición de arena de la punta de La Bajeta a Playa del Inglés project (Fig. 1).

Figure 1. Study area and locations of sand mobilization and sand collector zones. Source: IDECanarias, GRAFCAN, S.A. Canary Islands Government (2019). Coordinates

UTM. Zone 28 N. Ellipsoid WGS 84. Datum REGCAN95.

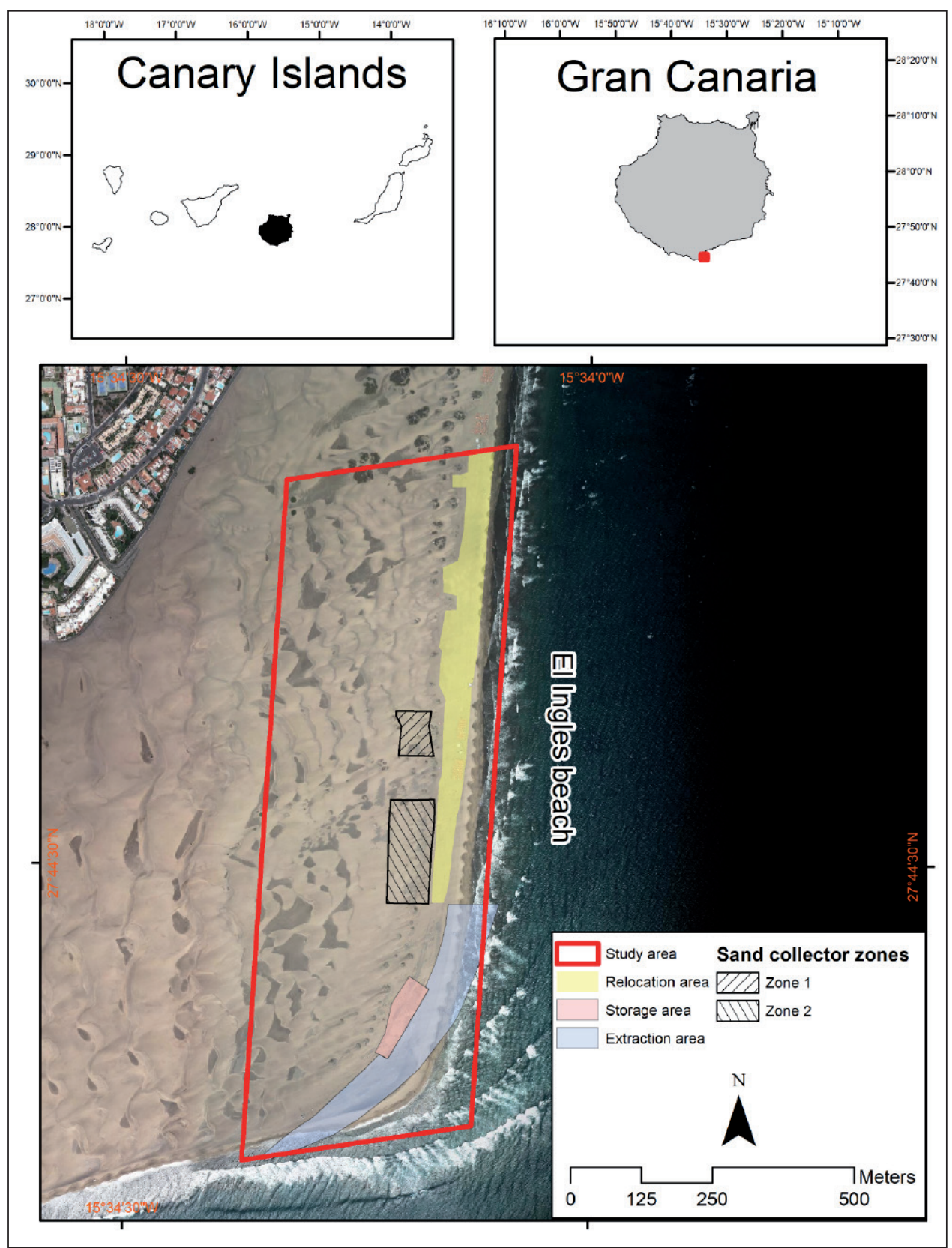




\section{METHODS}

\subsection{Project description}

The experiments carried out in the framework of the project included the reintroduction into the dune system of $60,000 \mathrm{~m}^{3}$ of sand from La Bajeta tip, as a source of sediments for dune formation. This was carried out before the SW storms occurred, in order to ensure their permanence in the system. For this, sand was dredged in the emerged area of this tip, setting it back up to a maximum defined by the inland beach profile registered in the last 40 years and relocating it in the El Inglés beach area. This sand relocation was carried out in three phases (Table 1). The relocated sand was exposed to the action of the wind, which would transport it to the foredune, where the planted $T$. moquinii specimens would intercept sediments, forming nebkhas and, subsequently, parabolic dunes and barchan dunes (Hernández-Cordero et al., 2012; Viera-Pérez, 2015). To favor the formation in the foredune of these first nebkhas associated with vegetation, a series of sand collectors were installed in various plots, and $21.04 \pm 8.63 \mathrm{~cm}$ tall $T$. moquinii specimens with roots around $23 \mathrm{~cm}$ long were planted, some of them associated with sand collectors (plant-collector units) and others not.

Table 1. Schedule of the actions carried out in the project. Source: Masdunas program.

\begin{tabular}{|l|l|}
\hline \multicolumn{1}{|c|}{ ACTION } & \multicolumn{1}{c|}{ DATES } \\
\hline Installation of sand collectors & $23 / 10 / 2018-9 / 11 / 2018$ \\
\hline Planting of T. moquinii specimens & $25 / 10 / 2018-13 / 11 / 2018$ \\
\hline & $22 / 10 / 2018-28 / 11 / 2018\left(18,930 \mathrm{~m}^{3}\right)$ \\
\hline Sand relocation & $06 / 05 / 2019-07 / 06 / 2019\left(24,705 \mathrm{~m}^{3}\right)$ \\
& $14 / 10 / 2019-08 / 11 / 2019\left(16,365 \mathrm{~m}^{3}\right)$ \\
\hline
\end{tabular}

The sand collectors and associated T. moquinii specimens were placed in two zones adjacent to the sand deposit area (Fig. 1). Zone 1 has a surface area of 4,599 $\mathrm{m}^{2}$ and Zone 2 14,085.09 $\mathrm{m}^{2}$. To determine the beneficial use or otherwise of sand collectors in each of these areas, two combinations were tested: i) the installation of sand collectors and the planting of associated T. moquinii specimens; and ii) only the planting of T. moquinii specimens.

In this way, Zone 1 (Fig. 2A) was subdivided into Zone 1 north (sand collectors with plants) and Zone 1 south (only plants). Zone 2 (Fig. 2B) was subdivided into Zone 2 north (sand collectors with plants), and Zone 2 south (including one area only with plants and another with both sand collectors and plants).

The spatial arrangement of the sand collectors and plants consisted of two or three lines parallel to the coast, depending on the characteristics of each area. The location of the collectors on each line was designed following a N-S arrangement. The location of the sand collectors of the different lines was designed following a NE-SW arrangement between them (Table 2).

The sand collectors installed in the plots had two typologies:

- Double semicircular collectors (according to the tested design, see Fernández-Cabrera et al., 2011), comprising two semicircles of wicker rods $2 \mathrm{~m}$ apart and placed transversely to the effective winds (NE-SW). Each semicircle is $2 \mathrm{~m}$ long (Fig. 3A).

- Circular sand collectors (experimental model), comprising a closed circle of wicker rods with a diameter of $2 \mathrm{~m}$. This model has an opening of about $50 \mathrm{~cm}$ on its south side to facilitate data collection (Fig. 3B).

The wicker rods of each collector are $1.8 \mathrm{~m}$ tall and were buried to a depth of about $70 \mathrm{~cm}$ ( $40 \%$ of their length) to ensure good resistance to the wind. Associated with each sand collector, two specimens (left and right facing seawards) of $T$. moquinii were planted to increase the chance of successful repopulation. In the 
case of the semi-circular collectors, the specimens were planted about $2 \mathrm{~m}$ from the second row. In the case of the circular collectors, they were planted inside. In the cases of plants with no sand collector, these were planted in pairs approximately $1.5 \mathrm{~m}$ apart and aligned from north (left) to south (right).

Table 2. Count and distribution of sand collectors and T. moquinii specimens.

\begin{tabular}{|c|c|c|c|c|c|c|c|c|}
\hline & & $\begin{array}{l}\text { Semicircular } \\
\text { sand collector }\end{array}$ & $\begin{array}{l}\text { Circular sand } \\
\text { collector }\end{array}$ & $\begin{array}{l}\text { T. moquiini without } \\
\text { sand collector }\end{array}$ & $\begin{array}{l}\text { Total sand } \\
\text { collectors }\end{array}$ & $\begin{array}{l}\text { Total T. moquinii } \\
\text { specimens }\end{array}$ & $\begin{array}{c}\text { Distance between } \\
\text { plants or between } \\
\text { sand collectors/T. } \\
\text { moquinii units }\end{array}$ & $\begin{array}{l}\text { Distance } \\
\text { beetwen } \\
\text { lines }\end{array}$ \\
\hline \multirow{2}{*}{ 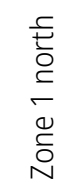 } & Line 1 & 2 & - & - & 2 & 4 & $7.6 \mathrm{~m}$ & \multirow[b]{2}{*}{$22 \mathrm{~m}$} \\
\hline & Line 2 & 3 & - & - & 3 & 6 & $10-11 \mathrm{~m}$ & \\
\hline \multirow{3}{*}{ 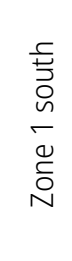 } & Line 1 & - & - & 4 & - & 8 & $5-8 \mathrm{~m}$ & \multirow{2}{*}{$14-21 \mathrm{~m}$} \\
\hline & Line 2 & - & - & 3 & - & 6 & $6-13 m$ & \\
\hline & Line 3 & - & - & 3 & - & 6 & $5-13 m$ & $25 \mathrm{~m}$ \\
\hline Total & & 5 & - & 10 & 5 & 30 & & - \\
\hline \multirow{3}{*}{ 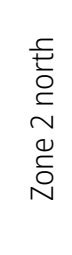 } & Line 1 & - & 8 & - & 8 & 16 & $6-11 \mathrm{~m}$ & \multirow{2}{*}{$17-22 \mathrm{~m}$} \\
\hline & Line 2 & 2 & 7 & - & 9 & 18 & $5-14 \mathrm{~m}$ & \\
\hline & Line 3 & 4 & 7 & - & 11 & 22 & 5-11 m & $13-22 \mathrm{~m}$ \\
\hline \multirow{3}{*}{ 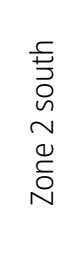 } & Line 1 & 8 & - & 2 & 8 & 20 & 4-11 m & \multirow{2}{*}{$14-22 \mathrm{~m}$} \\
\hline & Line 2 & 6 & - & 3 & 6 & 18 & $6-11 \mathrm{~m}$ & \\
\hline & Line 3 & 4 & - & 3 & 4 & 14 & $7-12 \mathrm{~m}$ & $7-20 \mathrm{~m}$ \\
\hline Total & & 24 & 22 & 8 & 46 & 108 & - & - \\
\hline
\end{tabular}

Source: Personal compilation based on Masdunas program.

\subsection{Monitoring methodology}

Monitoring the capacity of the sand collector installation and the planting of $T$. moquinii specimens for the formation of dunes was carried out by taking relative and absolute measurements in the field of the landforms and sand volumes around the plants and sand collectors. Similarly, measurements and observations were carried out with respect to the survival and morphological development of the plants. The sampling campaigns were carried out for 13 months, from November 2018 to December 2019, with a fortnightly frequency ( 25 campaigns). The wind speed and directions in this period were recorded every 10 minutes by a meteorological station located in El Inglés beach within the sand relocation area and less than $300 \mathrm{~m}$ from the sand collectors' installation and T. moquinii planting areas.

Monitoring of the planted T. moquinii specimens: the height and the largest and smallest diameters of each specimen were measured. With these data, its biovolume could be calculated by applying the following formula (Blanco Oyonarte and Navarro Cerrillo, 2003): 

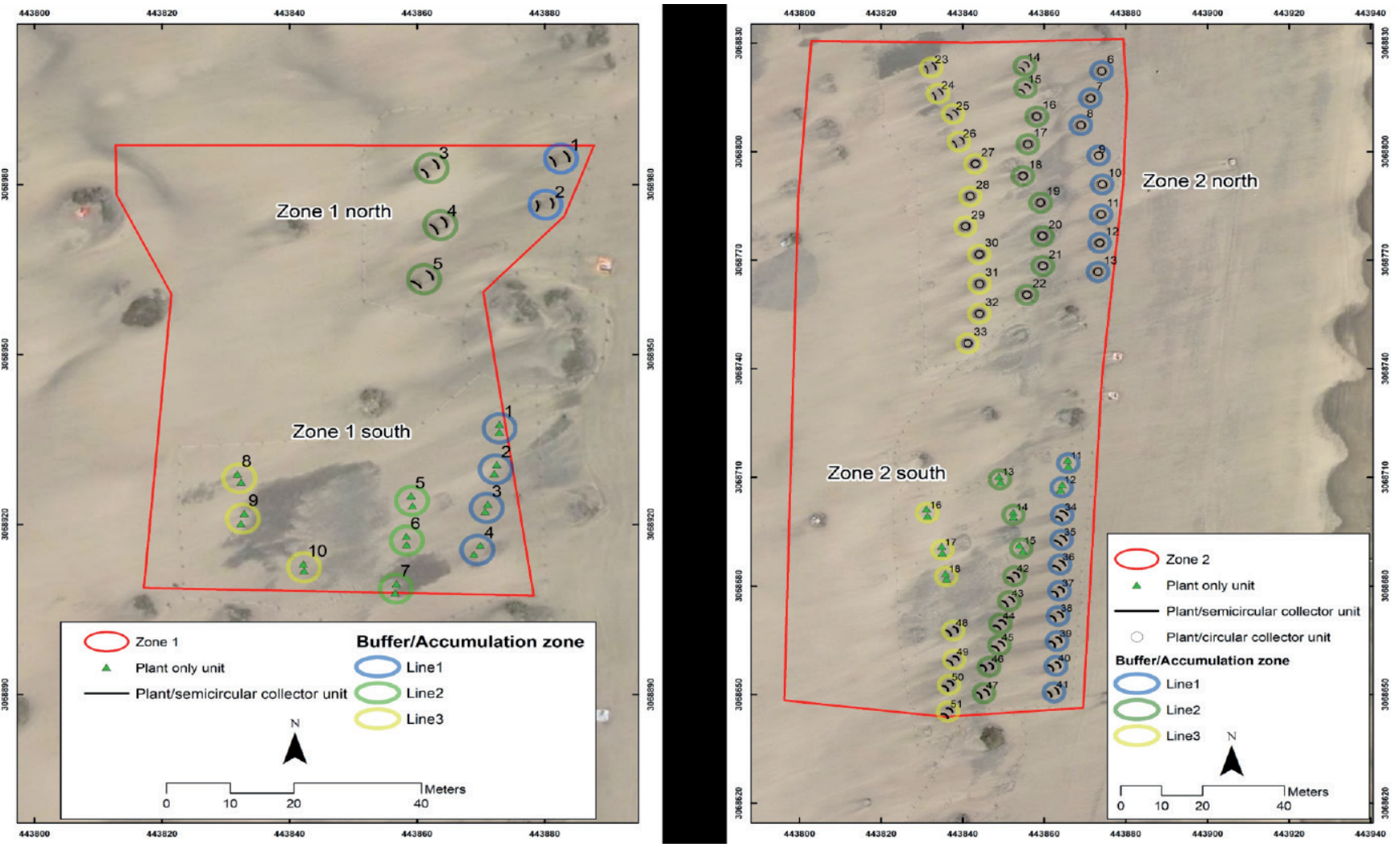

Figure 2. Layout of sand collectors and T. moquinii zones. A: Zone 1. B: Zone 2. Source: IDECanarias, GRAFCAN, S.A. Canary Islands Government (2019). Coordinates UTM. Zone 28 N. Ellipsoid WGS 84. Datum REGCAN95. Source: Own elaboration

Figure 3. Typologies of sand collectors and

natural T.moquinii specimens located in $E l$ Inglés beach foredune.

A) Double semicircu-

lar sand collector. B)

Circular sand collector.

C) Natural T. moquinii specimens. Source: Per-

sonal compilation.

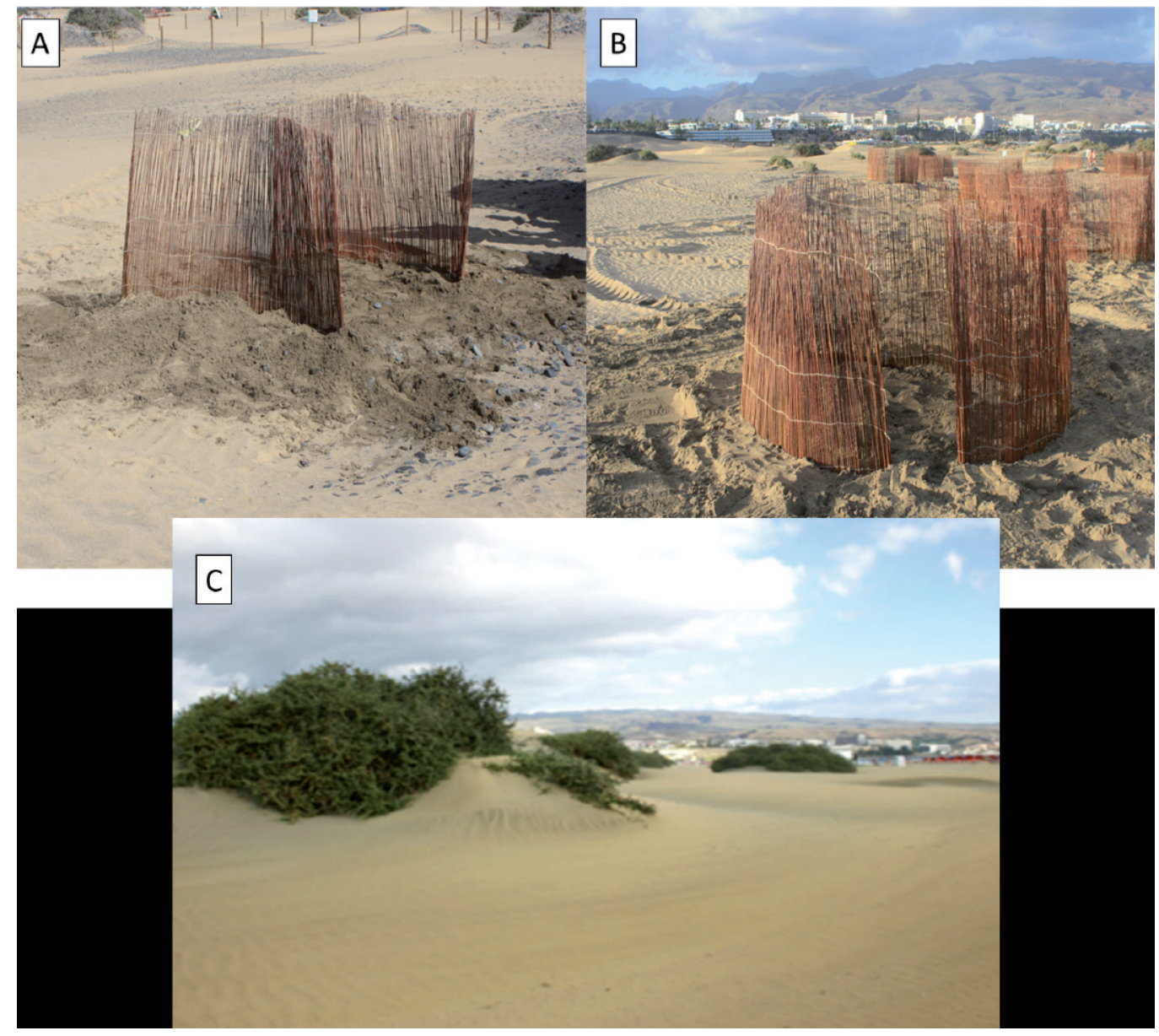




$$
B_{v}=\pi *\left[\frac{D m}{2}\right]^{2} * h
$$

where $B_{v}$ is the biovolume, $D m$ is the mean diameter and $h$ corresponds to the height of the plant.

This monitoring also enabled determination of the survival rate of the T. moquinii specimens, calculated as the percentage of the total number of specimens that remained alive. Likewise, information was collected on the state of vitality of each plant. The state of vitality was calculated according to a percentage scale. Each specimen was imaginarily divided into four equal parts. According to the number of parts that were green, the state of vitality was estimated as follows: excellent (> 75\%; dark blue columns in the fig. 4), good (50-75\%; orange columns in the fig. 4), regular (25-50\% and/or partially withered or dehydrated leaves; grey columns in the fig. 4), bad (5-25\% and/or withered or dehydrated leaves in a generalized way; yellow columns in the fig. 4), or dry (totally dry; light blue in the fig. 4).

Geomorphological monitoring: topographical measurements of the volumes of sand accumulated by the sand collectors and the associated T. moquinii specimens were taken (16 campaigns). This work was carried out with geomorphological control using a Leica TS06 Total Station with a laser device, which allowed detailed determination of morphological and volumetric changes. The topographical method was an inverse intersection from distances, from a series of fixed bases of known coordinates obtained using GPS (UTM-28N - Datum WGS84). To ensure complete data collection, the measurements were carried out in an area $5 \mathrm{~m}$ in diameter surrounding each collector-plant unit. With the collected data, digital elevation models (DEM) were elaborated by generating triangulated irregular networks (TIN), projected in UTM coordinates (WGS84). Subsequently, the TINs were converted to raster format with a pixel size of $0.10 \mathrm{~m}$. The last step in the data treatment consisted of crossing the raster models on different dates to evaluate the evolution of the volumetric variations associated with each collector-plant unit and determine the type of sand collector that, together with the associated T. moquinii specimens, was more effective in generating mounds. The sediment retention and nebkha dune formation capacity of the sand collectors and the associated T. moquinii specimens was evaluated by means of the difference between the maximum height reached within the influence zone between the last and the first monitoring campaign.

\section{RESULTS}

\subsection{Monitoring of planted T. moquinii specimens}

A progressive decrease in the survival rate of the plants was observed. The reduction was progressive and more pronounced in the specimens associated with sand collectors, with a survival rate at the end of the study period of $30 \%$, although in certain periods survival was $20 \%$ (Fig. 4). However, the survival rate of T. moquinii specimens without sand collector was more stable, remaining between $70 \%$ and $80 \%$ for a significant portion of the study period. Two periods were identified in which there was a more pronounced decrease in the survival rate, both in plants associated and not associated with sand collectors, January-March 2019 and November-December 2019. For specimens without sand collector, periods of slight recovery were observed in June and October 2019. Plants associated with sand collectors seemed to begin to recover or unearth from the end of November 2019 (Fig. 4).

The biovolume of T. moquinii specimens, both those associated and not associated with sand collectors, increased exponentially after their planting (Figs. 5A and 5B). In both cases, the increase in biovolume was gradual during the first 10 months before a considerable increase began to take place in September 2019. This upward trend was interrupted in November 2019 when the T. moquinii specimens began to decrease in biovolume.

Focusing only on the biovolume of the plants associated with sand collectors, differences according to the type of collector were observed. The seedlings associated with circular sand collectors (Fig. 5D) showed a 


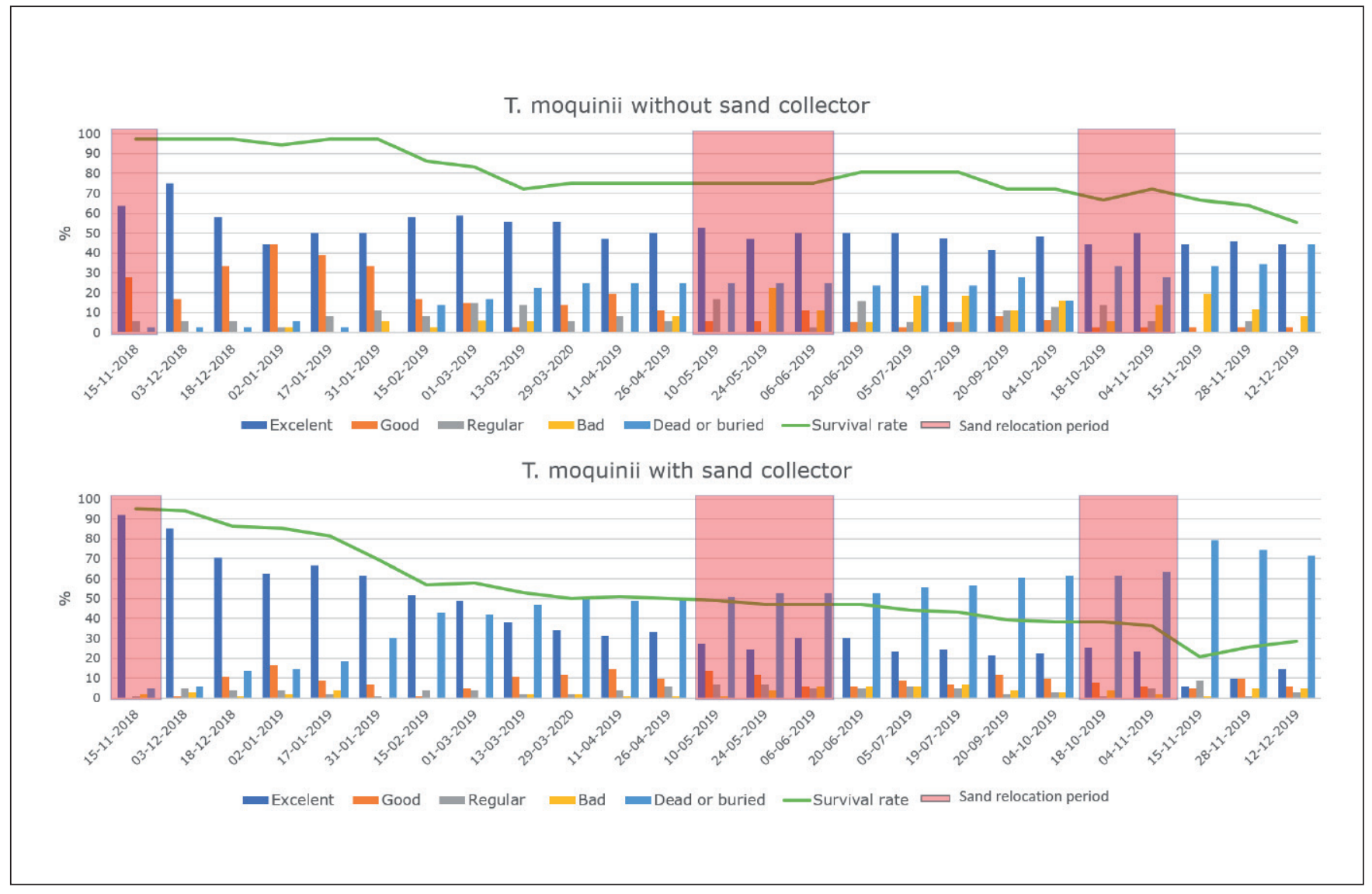

Figure 4. State of vitality and survival rate evolution of T. moquinii specimens. The top graph shows the evolution of specimens planted without sand collector (36), and the bottom graph shows the evolution of specimens planted with semicircular (58) and circular (44) sand collectors. Source: Personal compilation based on Masdunas program.

higher growth rate than those associated with double semicircular sand collectors (Fig. 5C). The latter plants accumulated a biovolume of less than $2 \mathrm{~m}^{3}$ during the first year, only exceeding this volume in November 2019. During the last months of the study there was a decrease in the biovolume of these plants. In this case, it is worth noting that the seedlings planted to the right (orange columns) of the double semicircular collectors generally presented a greater biovolume than that of the specimens planted to the left (blue columns). For their part, the T. moquinii specimens associated with circular sand collectors grew more than those associated with double semicircular collectors, and experienced progressive growth that conforms to an exponential model. At the end of October 2019, these specimens attained their maximum biovolume, exceeding $8 \mathrm{~m}^{3}$. As with the plants without sand collector and those associated with semicircular sand collectors, there was a decrease in biovolume in the last months of 2019 that broke the exponential growth trend of the series.

\subsection{Geomorphological monitoring}

Most of the collector-plant units accumulated sediment, increasing the height of the mound associated with its accumulation zone. However, in the case of $T$. moquinii specimens planted without a sand collector, the trend was not so clear and there were differences in behavior depending on the planting zone.

In Zone 1 north, all the elements accumulated sand in their area of influence, with the greatest height recorded for the collector-plant units located along Line 1 where values close to $1 \mathrm{~m}$ were reached. However, none of the specimens planted in this area remained alive at the end of the monitoring period. In Zone 1 south, where seedlings without a sand collector were planted, the difference in height in the volumes associated with these elements was lower than those of Zone 1 north, with heights ranging between $0.2 \mathrm{~m}$ 
A

T. moquinii without sand collector

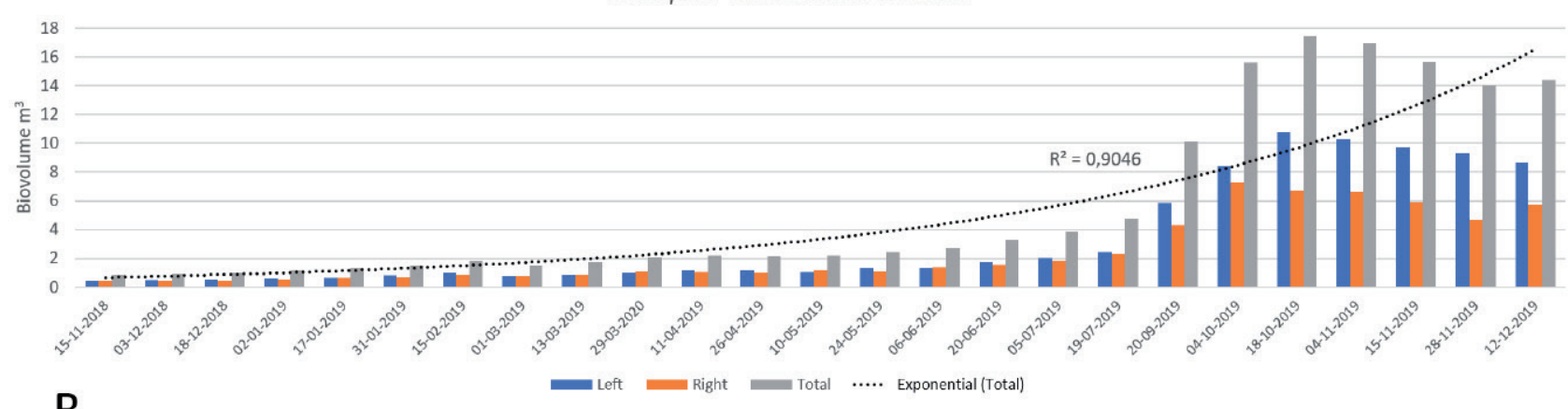

B

T. moquinii with sand collector

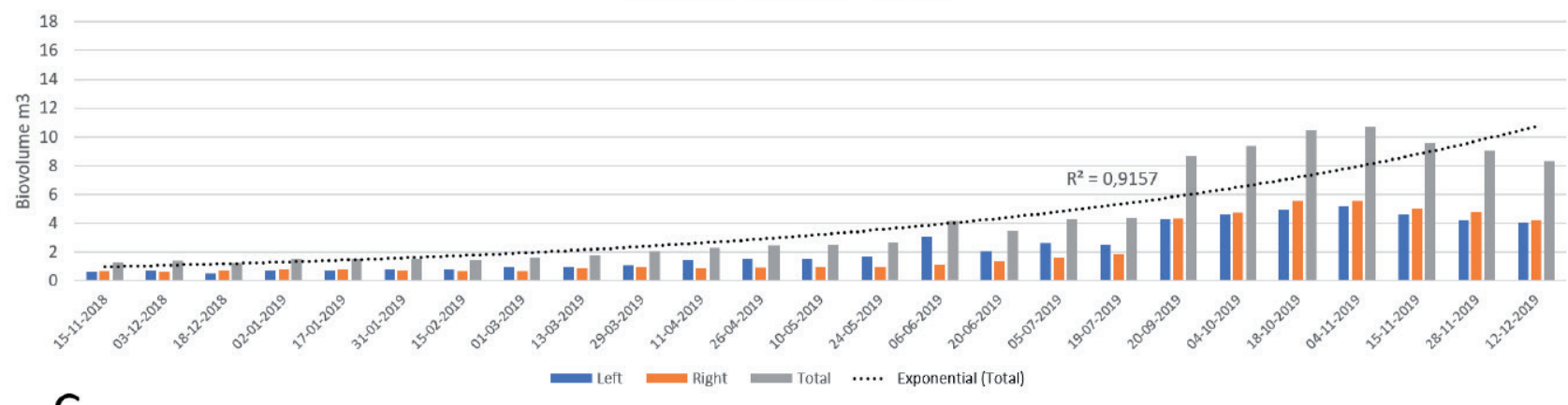

C

T. moquinii with semicircular sand collector

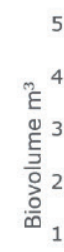
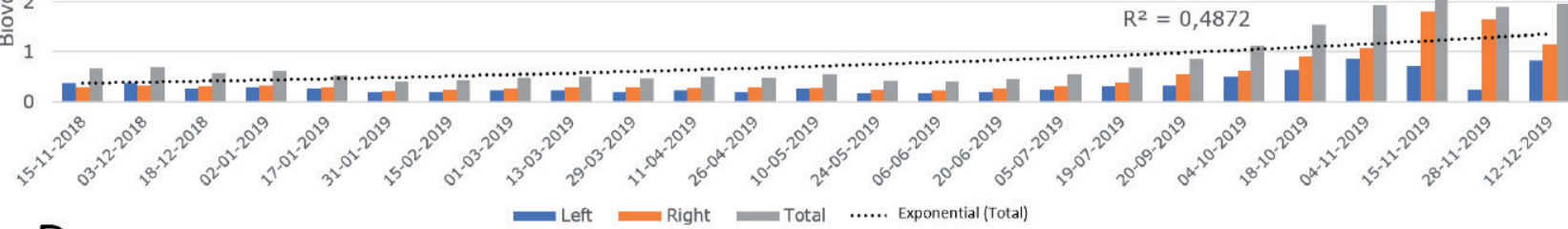

D

T. moquinii with circular sand collector

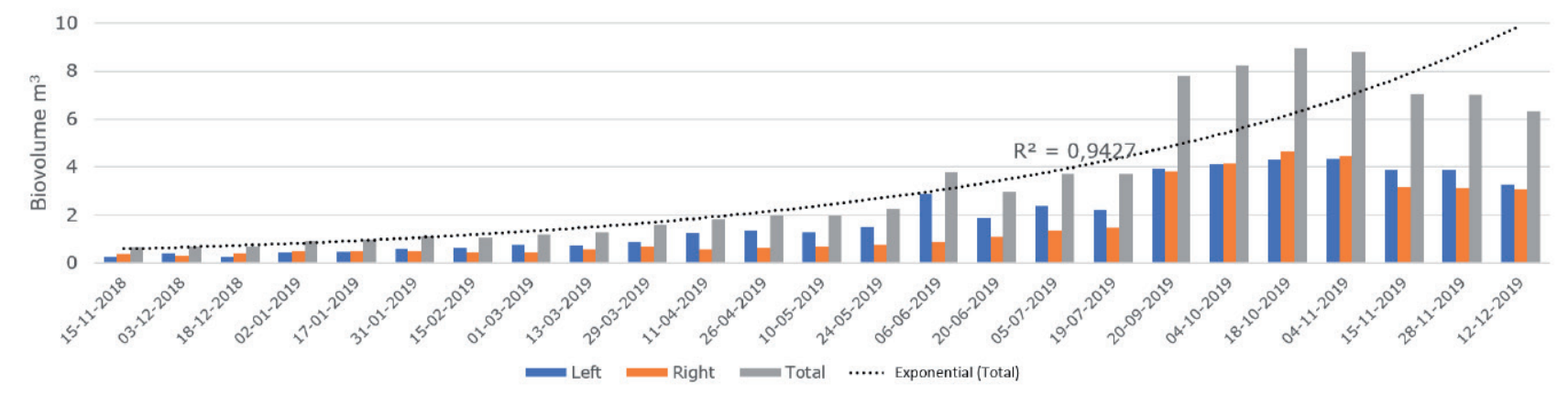

Figure 5. T. moquinii biovolume evolution. A) T. moquinii specimens without sand collector (36) ; B) T. moquinii specimens with sand collector (102) ; C) T. moquinii specimens associated with semicircular sand collector (58) ; and D) T. moquinii specimens associated with circular sand collector (44). Note diferences in vertical axis. Source: Personal compilation based on Masdunas program. 
A
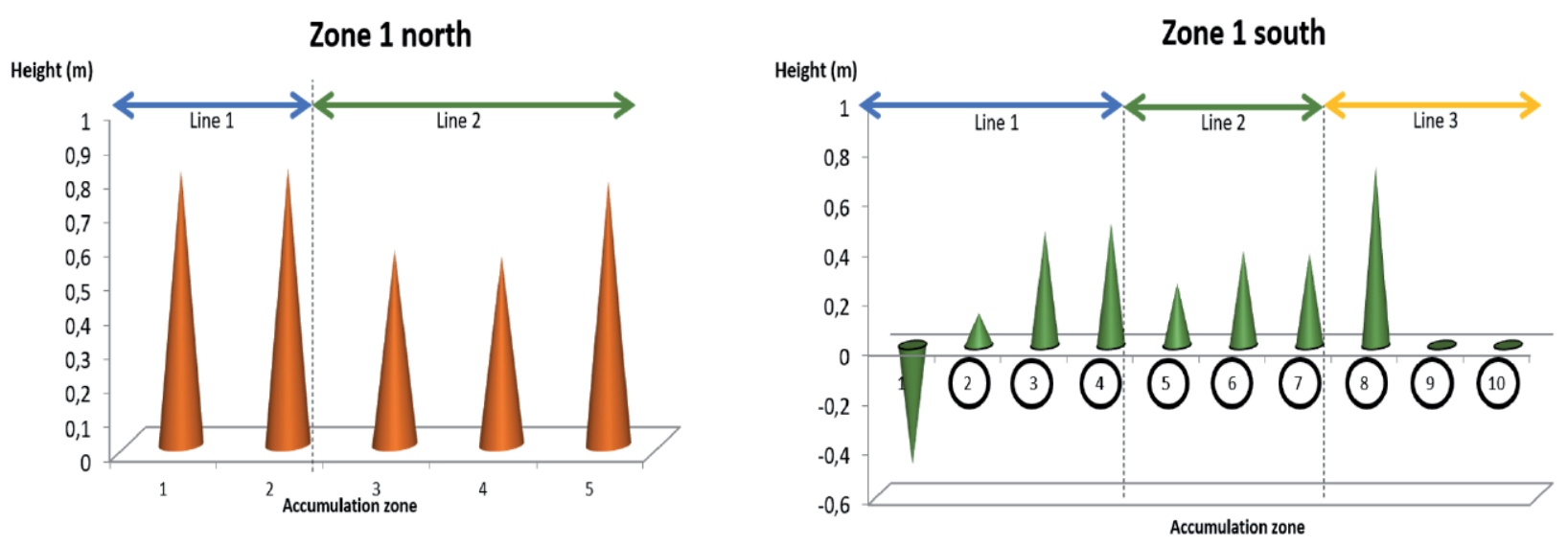

B

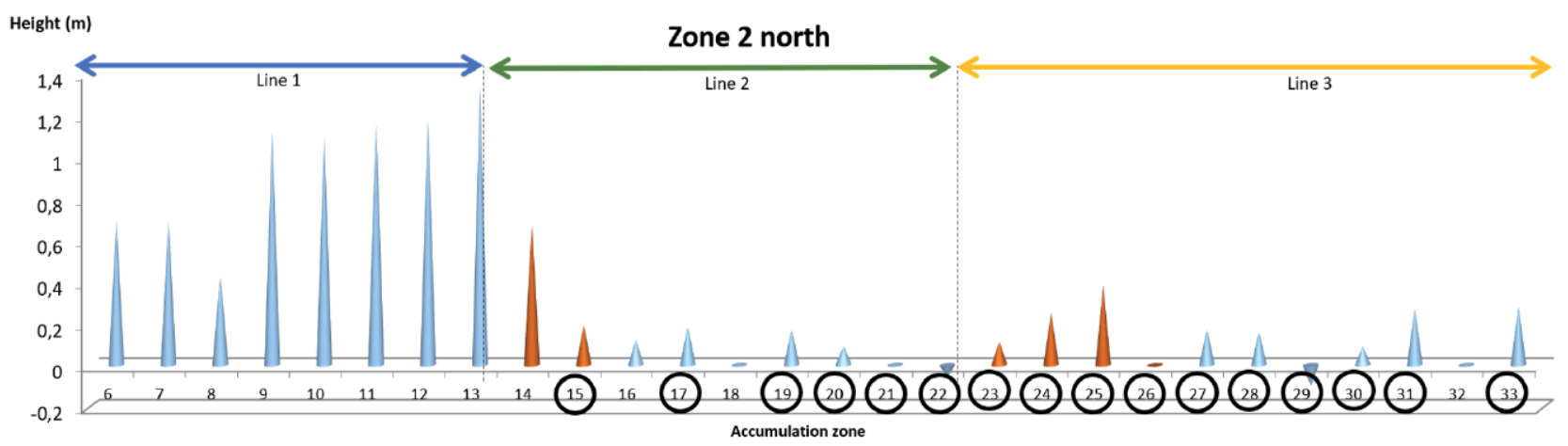

Height (m)

Zone 2 south

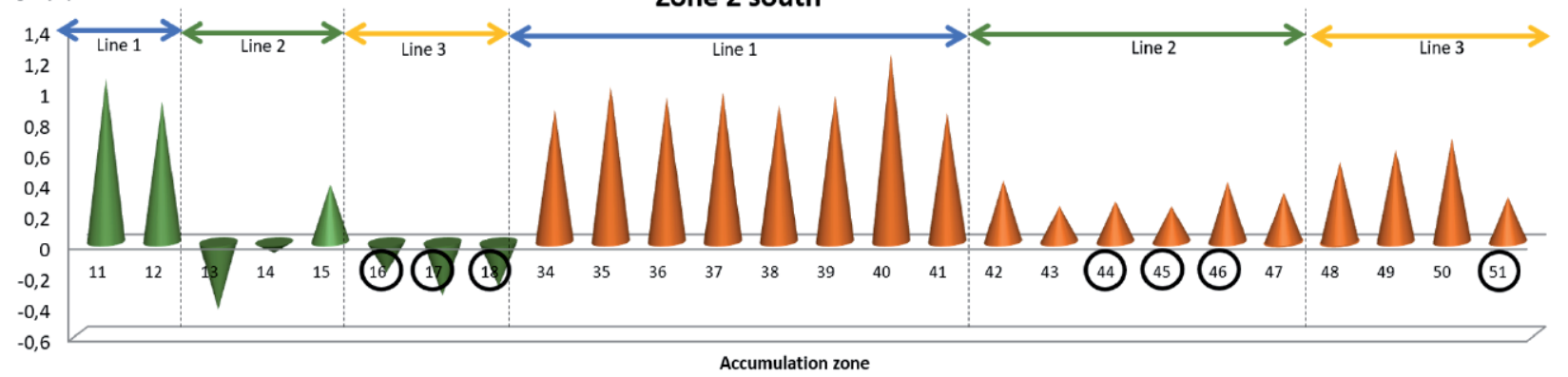

Semicircular sand collector

Circular sand collector

T. moquinii without sand collector

Figure 6. Maximum height difference in accumulation zones associated to sand collectors and T. moquinii specimens located in Zone 1 (A) and Zone 2 (B). Circled numbers correspond to T. moquinii specimens that were still alive at the end of the monitoring period. Source: Personal compilation based on Masdunas program.

and $0.8 \mathrm{~m}$. However, the final survival rate of T. moquinii specimens in this area was $90 \%$. In this area, there were some units around which accumulation was practically non-existent (Nos. 9 and 10) or which were eroded (No. 1) (Fig. 6A).

In Zone 2 north, where different types of sand collector were combined, the highest volumes of sediment occurred in the accumulation areas associated with the circular typology, reaching heights of around $1.4 \mathrm{~m}$ in the first line. In the interior lines, the height differences were smaller, producing erosion in some cases. In this case, the T. moquinii specimens planted in the first line had a zero survival rate. In Zone 2 south, there 
were differences between sediment accumulation generated by $T$. moquinii specimens with and without a sand collector. The plants without sand collector located in Line 1 accumulated volumes of sand with a height of around $1 \mathrm{~m}$, while those of the interior lines eroded, except for No. 15, which increased the height of its associated mound by $0.4 \mathrm{~m}$. On the other hand, the specimens associated with double semicircular collectors showed a positive increase in their sand mounds. In this case, the collector-plant units located on Line 1 generated sand mounds with heights greater than $1 \mathrm{~m}$, whereas the heights in the accumulation areas of Lines 2 and 3 ranged from $0.2 \mathrm{~m}$ to $0.8 \mathrm{~m}$. Again, for this area, no T. moquinii were still alive in Line 1 at the end of the monitoring period. In the case of plants without sand collector, the mortality of all specimens extended to Line 2 (Fig. 6B).

The sediment capture in the elements located in Zone 2 was higher than in Zone 1. Again, the collector-plant units and the plants without an associated collector, located in Line 1, accumulated a greater amount of sand than those located in Lines 2 and 3.

\section{DISCUSSION}

The monitoring of the experimental actions of dune restoration carried out in El Inglés beach, has allowed reliable data that can help to improve the recovery protocols of the coastal dune of an arid dune system. This will be not only useful for the recovery of the foredune of El Inglés beach, but can also be applied to other arid dune systems in the Canary Islands, Cape Verde Islands and the African coast (from Agadir to Mauritania), where T. moquinii plays a structural role in foredune formation (Hesp et al., 2021). In addition, this protocol could be adapted to other arid coastal dune systems in the world, although it must be adapted to their specific conditions.

In temperate climate zones, sand collectors have been widely used to facilitate the formation of dunes with morphologies appropriated to the characteristics of the intervened sites and the vegetation (Nordstrom, 2008; Grafals-Soto and Nordstrom, 2009; Grafals-Soto, 2012).

The inclusion of two experimental sand collector typologies has permitted the objective assessment of an efficient solution for the environmental restoration of foredunes in arid systems, a solution which is adapted to the particular geomorphological characteristics of the foredune in question by generating the mound morphology typical of this system (Hernández-Cordero et al., 2012). Thus, it has been found that the most efficient sand collector will be the type that gradually accumulates sediment, producing a balanced burial of the plants located in its area of influence and facilitating their progressive growth. This plant growth is in turn stimulated by its gradual burial in the sand, which enables a greater sand-holding capacity, allowing the development of mound dunes, a process described as a potential progressive growth system by Viera-Pérez (2015).

The use of sand collectors and T. moquinii specimens facilitated the generation of mound dunes at a greater speed and with a bigger height than the T. moquinii specimens planted without a collector. The mounds generated by the T. moquinii specimens without a sand collector were smaller than those associated with collectors and, in some cases mainly located in Zone 2 south, there was even a loss of height at the end of the study period (Fig. 6B). The difficulty, in this case, of the T. moquinii specimens to form and maintain mound dunes may be due, on the one hand, to having been planted in areas of wind flow acceleration caused by elements (beach equipment or other plants) situated in front of them that generate areas of high erosion. This seems to be the case of unit 1 (without sand collector) planted in Zone 1 south, located in an aeolian corridor generated by a pre-existing T. moquinii specimen (Fig. 2A). On the other hand, the wind flow acceleration that hinders sand accumulation around the specimens of $T$. moquinii without collector may also be due to the presence of stones or deflation surfaces in the planting area.

The efficiency in sand accumulation and the formed dune morphology depend on the characteristics of the sand collectors (Nordstrom, 2008). Although both sand collector types demonstrated their ability to retain sediment and generate associated mound dunes, the circular sand collectors achieved higher accumulation heights and greater stability of the generated mounds (Fig. 6). This is due to the fact that, unlike 
double semicircular sand collectors, this type of sand collector allows shelter of both the generated mound and the associated plants regardless of the direction of the effective winds. In contrast, in double semicircular collectors, the orientation of the installation is decisive, since they only induce dune formation downwind. This means that, in swirling wind conditions, the captured sediment moves, reducing the stability of the generated mound dune and varying its dimensions. Thus, effective SW, WSW and W winds (> $5.1 \mathrm{~m} / \mathrm{s}$ ) during the study period (Fig. 7) were responsible for remobilizing the sediment accumulated by the double semicircular collectors. Moreover, the plants associated with this type of sand collector would have been exposed to the direct action of the wind when not proceeding from the predominant direction, and thus would have been subjected to greater movement affecting their photosynthetic activity and growth (Smith and Ennos, 2003).

The participation of natural processes is essential to achieve a successful dune restoration (Gallego-Fernández et al., 2011; Ley, 2012). The wind transports the sand deposited in the back beach to the sand collector areas, where it sediments and favors the establishment of vegetation until it achieves a bearing that allows the balanced growth of both mound and plant. In this sense, the specimens planted next to the sand collectors must meet certain characteristics that allow plant survival after exposure to the natural conditions of the environment in which they are to be introduced. It is also important to consider how the collectors will affect the burial of the plant in the sand. The planted specimens need long roots to ensure rapid and effective rooting for plant stability and the acquirement of the water necessary for its survival which rises by capillarity from a water table that is usually, depending on the area, at depths of 20-40 cm (Viera-Pérez, 2015). Likewise, the aerial part of the plant must have sufficient length and size to cope with temporary burial (partial or absolute) and to ensure its progressive growth and development. When the necessary humidity is present, the vegetative growth of $T$. moquinii is greater during the hotter summer months (Viera-Pérez, 2015), and so its planting is recommended during the months of April-May.

The rapidly falling survival rate of the planted seedlings during the first 6 months (Fig. 4) suggests that the characteristics of the specimens that were introduced did not correspond to those indicated above, and that the plants could have been too small to be introduced into the system. The high mortality rate during these months could be due to the inability of the plants to reach the water table and/or the absence of fresh water supplies, as well as to sudden and rapid burial due to their small size and the large volumes of transported sediment. When there is a lag between collector installation and T. moquinii planting, the mound generated by the sand collector will accelerate the capillarity increase of the water table to levels where it can be captured by the roots of the plant that will subsequently be planted. However, in this case, collector installation and T. moquinii planting was undertaken simultaneously, which meant that insufficient time was allowed for the rise of the water table and hindered the rooting and survival of the planted specimens. This absence of lag could partly be compensated by applying irrigation, but this must be underground (not less than $20 \mathrm{~cm}$ ) in order to avoid the formation of saline crusts that can produce deflation zones around the plants. Nonetheless, the fact that survival was greater in plants not associated with sand collectors, added to the low or zero survival rate of specimens associated with sand collectors in the lines closest to the sand relocation area, reinforces the idea of sudden burial, suggesting the drowning of the plants located in the sand collectors, that were unable to cope with the sand accumulation. The high frequency of effective winds during the initial months after planting (Fig. 7) led to the inland transport of a large part of the volume from the first sand relocation (Table 1), which could also have caused the sudden burial of the newly planted specimens.

The practical absence of effective winds to transport sand into the system between the second and third sand relocations (Table 1) may be responsible for the second period of high mortality from October and November 2019, when the third sand relocation was performed and effective winds arose again (Fig. 7). The period between the second and third sand relocations coincided with the summer season when effective NE winds do not normally occur (Máyer Suárez et al., 2012). This lack of sediment mobility between sand relocations caused approximately $30,000 \mathrm{~m}^{3}$ worth of sand accumulation in the relocation area, which began to be transported to the collector areas in a massive way from October 2019. This massive entry of sediment into the collector areas during the last months of 2019 caused a new sudden burial of collectors and T. moquinii specimens that collapsed the system. This is reflected in a further decrease in the survival rate in this period (Fig. 4) and in a decrease in plant biovolume (Fig. 5). Again, the mortality rate due to burial was higher in 


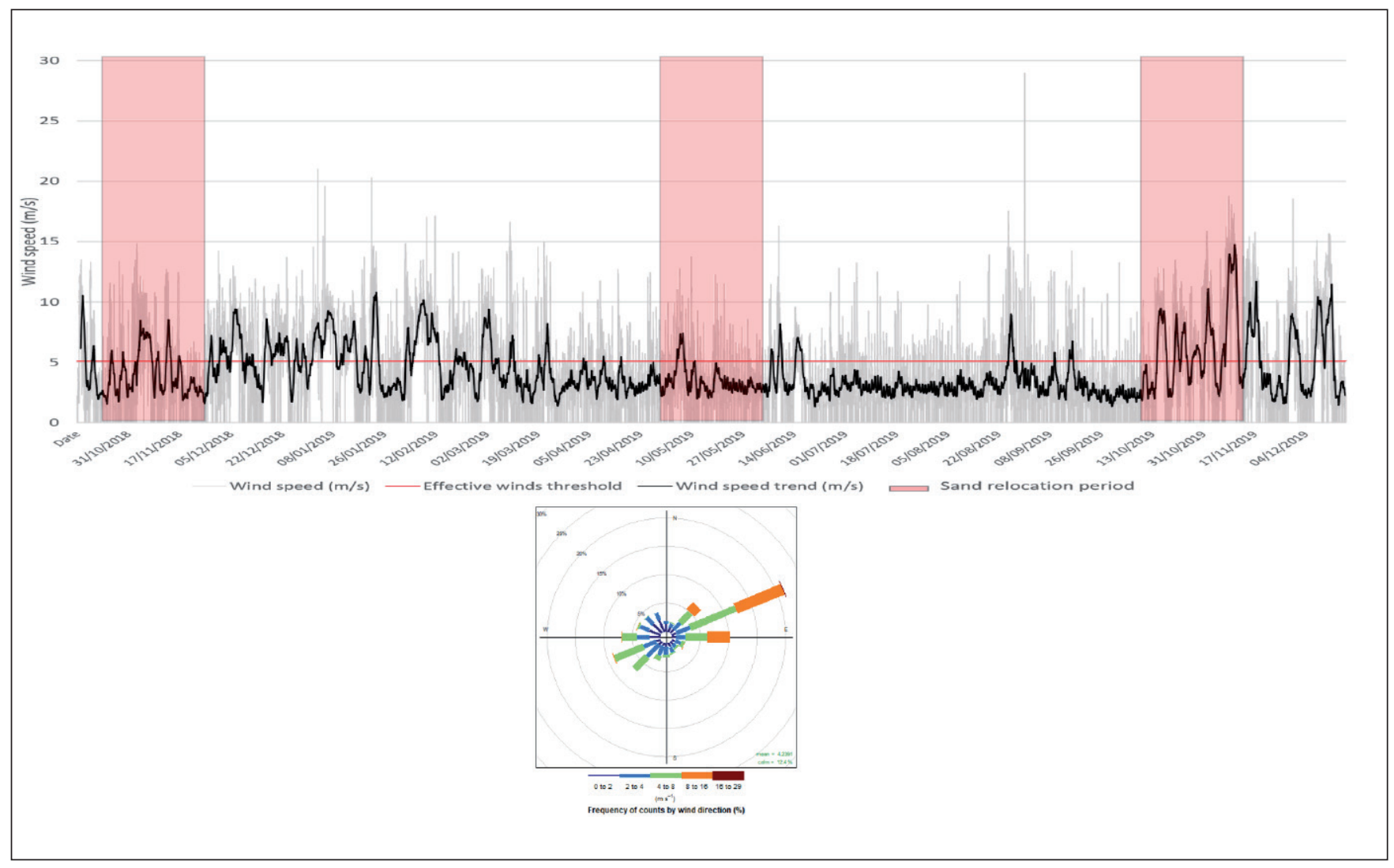

Figure 7. Wind speed and direction data series in El Inglés beach. Source: Personal compilation.

specimens associated with sand collectors than in specimens planted without a collector, which reinforces the hypothesis that mortality is associated with plant drowning by burial. In this sense, the massive entry of sediment into the system after the third relocation of sand may explain the fact that height increases occurred in areas of influence of $T$. moquinii specimens without a collector where the plant did not survive, as is the case of Line 1 in Zone 2 south (Fig. 6B). In these cases, the increase in height is not due to the formation of mound dunes, but rather to the advance of the sand front from the relocation.

It is important to highlight that the success of the management actions carried out depends to a large extent on the total elimination or reduction to compatible levels of the causes that have led to the alteration of the dune system (Ley et al., 2007). In this sense, the high occupancy and constant tourist activity in El Inglés beach represent a major impediment to the survival of T. moquinii specimens, to the generation of mound dunes and, even, to the maintenance of the natural dynamics that act as the engine of the system (Hernández-Cordero et al., 2017). Despite the use of protection systems (with enclosures and marking of the sand collector areas) and an information program for citizens (which included posters and informative days, among other strategies), user activities were observed that undoubtedly hindered the success of the restoration actions. On the one hand, invasion by users of the collector areas caused trampling of the planted seedlings, which would have been another important cause of plant mortality. On the other hand, the use of the collectors by users as windbreaks or even as clotheslines had a direct impact on the sand mounds generated, which were often flattened by the user to make them more comfortable to lie on. This would have reduced collector porosity, modifying its sediment retention capacity and similarly affecting the incipient dunes.

The construction or installation of windbreak structures (known locally as goros), as well as the presence of artificial elements installed by the beach management, such as trash cans or kiosks, interacted with the aeolian dynamics of the system and altered the natural transport of the sand. These obstacles led, in some cases, to the acceleration of transport in their area of influence, causing the loss of sedimentary accumulations in their surroundings (Sanromualdo-Collado et al., 2021). The loss of sediment resulting from wind acceleration due to the presence of obstacles would have led to the uprooting of the plants and another cause of their mortality. 
Despite the possible impact of users activities in the restoration project, the results have proven to be invaluable with respect to improving the restauration protocols in arid dune systems. The results of the present study form the basis for a second project that will be executed within the framework of the MASDUNAS2 program over the course of 2021. In this second phase, around 100 new specimens of T. moquinii will be planted, including a group cultivated in long pots to prolong the roots. In addition, monthly irrigation of the planted seedlings for a year is proposed, following the recommendations of Viera-Pérez (2015). These specimens will be planted on the dunes generated by the collectors during the first restoration trial, replacing the lost specimens and giving a second chance to foredune restoration in a context without extraordinary sediment contributions and with mound dunes already formed.

Finally, the usefulness of the data obtained from scientific monitoring that took place has been shown. As an experimental project, the data offers the possibility of further analysis, with the results highlighting the need to disaggregate or aggregate certain data in order to perform a more exhaustive analysis of the scientific monitoring data in future research.

\section{CONCLUSIONS}

Valuable conclusions can be drawn from this experimental project to restore the coastal dune of El Inglés beach. The results showed that the installation of double semicircular collectors and circular collectors is effective for the generation of mound dunes, although the dunes generated by circular collectors are larger and have greater stability. Consequently, the T. moquinii specimens associated with sand collectors must be adapted to the conditions of the environment in which they are to be planted. They must be hardened plants with long roots and stems that allow their survival against burial and a lack of fresh water from the water table.

The results of this study suggest that the main cause of plant mortality was the sudden and massive burial of specimens. To avoid this, larger specimens should be planted, allowing burial to be more progressive. Moreover, the accumulation of sand from contributions in the relocation area should be avoided. It is essential not to make new contributions until the volume of sand introduced in the previous sand relocation has been completely incorporated inside the system by aeolian transport, in order to avoid the sudden burial of collectors and plants.

It is suggested that the planting of T. moquinii specimens in the foredune of El Inglés beach should be carried out from the months of April-May, so that a minimum of 5 months elapse to allow the plants to reach a size capable of supporting the burial that can be caused by the effective winds of autumn. There should be a lag between the installation of sand collectors and the planting of T. moquinii specimens in order to allow the ascent by capillarity of fresh water from the water table. In the absence of this lag, or if it is insufficient for the moisture to be made available to the plant, it is necessary to assist the planting of seedlings with underground irrigation. Nevertheless, the actions of certain users represent a handicap for the success of the restoration program, despite the efforts made in protection and information systems.

Finally, the results highlight the need to implement a scientific monitoring program that collects the results of any foredune restoration project. Monitoring allows early detection of problems that may occur and the establishment of rapid adaptive response measures. In addition, it allows determination of which measures are appropriate and which are not for future restoration projects.

The findings of this study make the Experiencia piloto de reposición de arena desde la punta de La Bajeta a la Playa del Inglés a valuable reference to help the development of a more effective coastal dune restoration protocol applicable in arid dune systems.

\section{Acknowledgements}

This work is a contribution of project CSO2016-79673-R (National R\&D\&i Plan, Spain) co-financed with ERDF funds. The results shown are derived from the "Experiencia piloto de reposición de arena desde la punta 
de la Bajeta a la playa del Inglés", within the MASDUNAS Program of the Cabildo Insular de Gran Canaria, executed by the public company Gesplan, S.A. First author is beneficiary of a PhD contract of the Spanish Ministry of Economy, Industry and Competitiveness, supported by the European Social Fund (ESF). The authors would like to thank the Gran Canaria Island Council for integrating the experiments in the Program and in the project indicated above. They especially want to express their gratitude to the President of the Island Council, Antonio Morales, as well as to Marino Alduán, the Environmental Councilors J. Manuel Brito and M. Ángel Rodríguez, the General Director of the Environment, Manuel Amador, the previous Director of the Special Natural Reserve Dunas de Maspalomas, Miguel Ángel Peña, and its current Director, Orlando Marrero. They also want to express their special thanks to Dr Emma Pérez-Chacón Espino, Professor of Physical Geography at ULPGC, and Dr Patrick A. Hesp, Strategic Professor in Coastal Studies in Flinders University (Australia), for their unconditional support in the development of the experiments. Our thanks are also given to the staff of Gesplan, S.A., especially to Ramón Gallo and Lidia Suárez, as well as Pedro Monroy and the field crew staff, for their professionalism and collaboration at all times throughout the execution of the project. To elittoral ${ }^{\circledR}$ staff, especially its co-director Óscar Bergasa, and Sara García, who completed the data collection in the last stage of the project. The design of the experiments and their monitoring, as well as the scientific coordination during their execution and subsequent observations, correspond to the Group of Physical Geography and Environment of the Institute of Oceanography and Global Change (IOCAG) of the ULPGC, an R\&D\&i CSIC-associate unit (Ocean and Climate Unit).

\section{Conflicts of interest and authorship statement}

The authors declare that they have no known any existing or potential conflict of interest in relation to the work reported in this paper. A. Hernández-Cordero and M. Viera-Pérez were hired by the companies Gesplan, S.A. and elittoral ${ }^{\circledR}$ for the monitoring of sand volumes and T. moquinii specimens, within the framework of the "Experiencia piloto de reposición de arena desde la punta de La Bajeta a la Playa del Inglés" project.

Author statement: Abel Sanromualdo-Collado, Data curation, Formal analysis, Investigation, Methodology, Writing - original draft, Writing - review \& editing. Antonio I. Hernández-Cordero, Data curation, Formal analysis, Methodology, Writing - original draft. Manolo Viera-Pérez, Data curation, Formal analysis, Methodology, Writing - original draft. Juan B. Gallego-Fernández, Methodology, Supervision, Writing - review \& editing. Luis Hernández-Calvento, Supervision, Writing - original draft, Writing - review \& editing, Funding acquisition.

\section{REFERENCES}

Alonso, I., Montesdeoca I., Vivares, A. \& Alcantara-Carrio, J. (2001). Variabilidad granulometrica y de la linea de costa en las playas de El Ingles y Maspalomas (Gran Canaria). Geotemas, 3(1), 39-42.

Blanco Oyonarte, P. \& Navarro Cerrillo, R.Mª (2003). Aboveground phytomass models for major species in a shrub ecosystems of western Andalusia. Investigación Agraria. Sistemas y Recursos Forestales, 12(3), 47-55.

Burke, A., Newton, R., Boyce, D. Kolberg, H. \& Brunner, I. (2011). Reestablishing a Keystone Species in an Arid Coastal Environment: Saltbush (Salsola nollothensis) in Namibia. Ecological Restoration, 29(1-2), 25-34. https://doi.org/10.3368/ er.29.1-2.25

Cabrera-Vega, L.L., Cruz-Avero, N., Hernández-Calvento, L., Hernández-Cordero, A.I. \& Fernández-Cabrera, E. (2013). Morphological changes in dunes as an indicator of anthropogenic interferences in arid dune fields. Journal of Coastal Research, (165), 1271-1276. https://doi.org/10.2112/SI65-215.1

Castro, C. (1988). The artificial construction of foredunes and the interference of dune-beach interaction, Chile. Journal of Coastal Research SI, (3), 103-109. http://www.jstor.org/stable/40928735

Castro Avaria, C. (1987). Transformaciones geomorfológicas recientes y degradación de las dunas de Ritoque. Revista de Geografía Norte Grande, (14), 3-13. 
Di Paola, G., Rodríguez, G., \& Rosskopf, C. M. (2020). Short- to mid-term shoreline changes along the southeastern coast of Gran Canaria Island (Spain). Rendiconti Lincei. Scienze Fisiche e Naturali, 31(1), 89-102. https://doi.org/10.1007/ s12210-020-00872-3

Fernández-Cabrera, E., Cruz-Avero, N., Hernández-Cordero, A.I., Viera-Pérez, M., Hernández-Calvento, L. \& Pérez-Chacón, E. (2011). Diseño experimental y seguimiento de captadores para la regeneración de la duna costera de playa del Inglés (Gran Canaria). In: XI Jornadas Españolas de Costas y Puertos. Las Palmas de Gran Canaria (pp. 375-382).

Fontán-Bouzas, Á., Alcántara-Carrió, J., Albarracín, S., Baptista, P., Silva, P. A., Portz, L., \& Manzolli, R. P. (2019). Multiannual Shore Morphodynamics of a Cuspate Foreland: Maspalomas (Gran Canaria, Canary Islands). Journal of Marine Science and Engineering, 7(11), 416. https://doi.org/10.3390/jmse7110416

Gallego-Fernández, J.B. \& Martínez, M.L. (2011). Environmental filtering and plant functional types on Mexican foredunes along the Gulf of Mexico. Ecoscience, (18), 52-62. https://doi.org/10.2980/18-1-3376

García-Romero, L., Hernández-Cordero, A.I., Fernández-Cabrera, E., Peña-Alonso, C., Hernández-Calvento, L. \& Pérez-Chacón, E. (2016). Urban-touristic impacts on the aeolian sedimentary systems of the Canary Islands: Conflict between development and conservation. Is/and Studies Journal, (11), 91-112. http://hdl.handle.net/10553/52597

García-Romero, L., Delgado-Fernández, I., Hesp, P.A., Hernández-Calvento, L., Viera-Pérez, M., Hernández-Cordero, A.I., Cabrera-Gámez, J. \& Domínguez-Brito, A.C. (2019). Airflow dynamics, vegetation and aeolian erosive processes in a shadow zone leeward of a resort in an arid transgressive dune system. Aeolian Research, (38), 48-59. https://doi. org/10.1016/j.aeolia.2019.03.006

García-Romero, L., Hernández-Cordero, A.I., Hesp, P.A., Hernández-Calvento, L. \& Santana del Pino, A. (2021). Decadal monitoring of Traganum moquinii's role on foredune morphology of an human impacted arid dunefield. Science of the Total Environment, (758), 143802. https://doi.org/10.1016/j.scitotenv.2020.143802

Gesplan (2007). Proyecto piloto de refuerzo de las poblaciones de balancones. Informe inédito.

Gómez-Pina, G., Muñoz-Pérez, J. J., Ramírez, J. L., \& Ley, C. (2002). Sand dune management problems and techniques, Spain. Journal of Coastal Research, (36), 325-332. https://doi.org/10.2112/1551-5036-36.sp1.325

Grafals-Soto, R. \& Nordstrom, K. (2009). Sand Fences in the Coastal Zone: Intended and Unintended Effects. Environmental Management, 44 (3), 420-429. https://doi.org/10.1007/s00267-009-9331-7

Grafals-Soto, R. (2012). Effects of sand fences on coastal dune vegetation distribution. Geomorphology, (145-146), 45-55. https://doi.org/10.1016/j.geomorph.2011.12.004

Hernández-Calvento, L. (2006.) Diagnóstico sobre la evolución del sistema de dunas de Maspalomas: (1960-2000). Cabildo Insular de Gran Canaria, Las Palmas de Gran Canaria.

Hernández-Calvento, L., Jackson, D.W.T., Medina, R., Hernández-Cordero, A.I., Cruz-Avero, N. \& Requejo, S. (2014.) Downwind effects on an arid dunefield from an evolving urbanised area. Aeolian Research, (15), 301-309. https:// doi.org/10.1016/j.aeolia.2014.06.007

Hernández-Cordero, A.I., Pérez-Chacón Espino, E. \& Hernández-Calvento, L. (2012). La investigación como soporte de la gestión: El ejemplo de la duna costera (foredune) de Maspalomas (Gran Canaria, Islas Canarias). La gestión Integr. Play. y dunas Exp. en Latinoamérica y Eur. Monogr. la Soc. d'Història Nat. les Balear, 19 (pp. 289-306).

Hernández-Cordero, A.I., Hernández-Calvento, L. \& Pérez-Chacón Espino, E. (2017). Vegetation changes as an indicator of impact from tourist development in an arid transgressive coastal dune field. Land use policy, (64), 479-491. https://doi.org/10.1016/j.landusepol.2017.03.026

Hernández-Cordero, A.I., Hernández-Calvento, L., Hesp, P.A. \& Pérez-Chacón, E. (2018). Geomorphological changes in an arid transgressive coastal dune field due to natural processes and human impacts. Earth Surface Processes and Landforms, (43), 2167-2180. https://doi.org/10.1002/esp.4382

Hernández-Cordero, A.I., Peña-Alonso, C., Hernández-Calvento, L., Ferrer-Valero, N., Santana-Cordero, A.M., García-Romero, L. \& Pérez-Chacón Espino, E. (2019). Aeolian Sedimentary Systems of the Canary Islands. In: Morales, J.A. (ed.), The Spanish Coastal Systems (pp. 699-725). Springer International Publishing, Cham. https://doi.org/10.1007/978-3319-93169-2_30

Hesp, P.A., Hernández-Calvento, L., Hernandez-Cordero, A., Gallego-Fernandez, J., Garcia Romero, L., Miot da Silva, G. \& Ruz, M-H. (2021). Nebkha development and sediment supply. Science of the Total Environment, (144815), https://doi. org/10.1016/j.scitotenv.2020.144815. 
Ley, C., Gallego-Fernández, J.B., Vidal, C. (2007). Manual de restauración de dunas costeras. Dirección General de Costas. Ministerio de Medio Ambiente y Medio Rural y Marino.

Ley, C. (2012). Restauración de dunas. El caso español. In: Rodríguez-Perea, A., Pons, G.X., Roig-Munar, F.X., Martín-Prieto, J.A., Mir-Gual, M. \& Cabrera, J.A. (eds.), La Gestión Integrada de Playas y Dunas: Experiencias En Latinoamérica y Europa, Monografies de La Societat d'Història Natural de Les Balears (p.402). Palma de Mallorca.

Lithgow, D., Martínez, M.L., Gallego-Fernández, J.B., Hesp, P.A., Flores, P., Gachuz, S., Rodríguez-Revelo, N., Jiménez-Orocio, O., Mendoza-González, G. \& Álvarez-Molina, L.L. (2013). Linking restoration ecology with coastal dune restoration. Geomorphology, (199), 214-224. https://doi.org/10.1016/j.geomorph.2013.05.007

Lubke, R.A. (2013.) Restoration of dune ecosystems following mining in Madagascar and Namibia: contrasting restoration approaches adopted in regions of high and low human population density. In: Martínez, M.L., Gallego-Fernández, J.B. \& Hesp, P.A. (eds.), Chapter 13. Restoration of Coastal Dunes. Springer Verlag, Germany (pp. 199-215). https://doi.org/10.1007/978-3-642-33445-0_13

Martínez, M.L., Hesp, P.A. \& Gallego-Fernández, J.B. (2013). Coastal Dune Restoration: Trends and Perspectives. In: Martínez, M.L., Gallego-Fernández, J.B. \& Hesp, P.A. (eds.), Chapter 20. Restoration of Coastal Dunes. Springer Verlag (pp.323-339). Germany. https://doi.org/10.1007/978-3-642-33445-0_20

Máyer Suárez, P., Pérez-Chacón Espino, E., Cruz-Avero, N., \& Hernández-Calvento, L. (2012). Características del viento en el campo de dunas de Maspalomas (Gran Canaria, islas Canarias, España). Nimbus, (29-30), 381-397.

Ministerio de Medio Ambiente (2007). Estudio integral de la playa y dunas de Maspalomas (Gran Canaria). Madrid (Spain).

Nordstrom, K.F. (2008). Beach and Dune Restoration. Cambridge University Press. https://doi.org/10.1017/ CBO9780511535925

Peña-Alonso, C., Gallego-Fernández, J.B., Hernández-Calvento, L., Hernández-Cordero, A.I. \& Ariza, E. (2018). Assessing the geomorphological vulnerability of arid beach-dune systems. Science of the Total Environment, (635), 512-525. https://doi.org/10.1016/j.scitotenv.2018.04.095

Pérez-Chacón, E., Hernández-Calvento, L., Hernández-Cordero, A.I., Máyer Suárez, P., Romero, L.E., Alonso, I., Mangas, J., Menéndez, I., Sánchez, I., Ojeda, J., Ruiz, P. \& Alcántara, J. (2007). Maspalomas: claves científicas para el análisis de su problemática ambiental. Universidad de Las Palmas de Gran Canaria.

Sanromualdo-Collado, A., García-Romero, L., Peña-Alonso, C., Hernández-Cordero, A. I., Ferrer-Valero, N., \& Hernández-Calvento, L. (2021). Spatiotemporal analysis of the impact of artificial beach structures on biogeomorphological processes in an arid beach-dune system. Journal of Environmental Management, (282), 111953. https://doi. org/10.1016/j.jenvman.2021.111953

Smith, A., Jackson, D. W. T., Cooper, J. A. G., Beyers, M., \& Breen, C. (2021). Whole-island wind bifurcation and localized topographic steering: Impacts on aeolian dune dynamics. Science of The Total Environment, (763), 144444. https:// doi.org/10.1016/j.scitotenv.2020.144444

Smith, A.B., Jackson, D.W.T., Cooper, J.A.G. \& Hernández-Calvento, L. (2017). Quantifying the role of urbanization on airflow perturbations and dunefield evolution. Earth's Future, (5), 520-539. https://doi.org/10.1002/2016EF000524

Smith, V.C. \& Ennos, A.R. (2003). The effects of air flow and stem flexure on the mechanical and hydraulic properties of the stems of sunflowers Helianthus annuus I. Journal of Experimental Botany. https://doi.org/10.1093/jxb/erg068

Viera-Pérez, M. (2015). Estudio detallado de la duna costera de Maspalomas (Gran Canaria, Islas Canarias): interacción 'Traganum moquinii' - dinámica sedimentaria eólica en un entorno intervenido. Recomendaciones de cara a su gestión [Tesis doctoral, Universidad de Las Palmas de Gran Canarias].

Viera-Pérez, M., Hernández-Calvento, L., Hesp, P.A. \& Santana-del Pino, A. (2019). Effects of artificial light on flowering of foredune vegetation. Ecology, (100), 1-10. https://doi.org/10.1002/ecy.2678 